\title{
Kolaborasi Peta Indonesia Dan Model Pembelajaran Teams Games Tournaments (TGT)
}

\author{
Siti Halimatus Sakdiyah ${ }^{a, 1^{*}}$, Triwahyudianto ${ }^{\mathrm{b}, 2}$, Harun ${ }^{\mathrm{c}, 3}$ \\ ${ }^{a}$ Universitas Kanjuruhan Malang, Indonesia \\ ${ }^{1}$ halimatus@unikama.ac.id* \\ *korespondensi penulis
}

\section{Informasi artikel \\ Received : \\ September 26, \\ 2018. \\ Revised : \\ December 10,2018. \\ Publish : \\ January 01, 2019.}

Kata kunci:

Peta Indonesia,

Team Games

Tournament,

Aktivitas siswa,

Hasil belajar

\begin{abstract}
ABSTRAK
Penggunaan media Peta Indonesia dan model pembelajaran TGT yang melibatkan siswa sebagai tutor sebaya mudah diterapkan tanpa ada perbedaan antara siswa yang pandai atau kurang, dimana kolaborasi ini dikemas dalam permainan agar menjadi pembelajaran yang lebih efektif dan menyenangkan, sehingga dapat meningkatkan aktivitas dan hasil belajar. Hasil observasi menunjukkan proses pembelajaran terjadi searah sehingga siswa lebih asyik bergurau daripada belajar. Dari kenyataan ini menyebabkan hasil belajar siswa cenderung rendah. Terbukti hanya 39,28\% dari 28 siswa yang mencapai ketuntasan belajar, sedangkan $61,11 \%$ nilainya dibawah KKM 75. Tujuan penelitian untuk mendiskripsikan peningkatan aktivitas dan hasil belajar siswa kelas IV SD Islam Al Hikmah. Rancangan penelitian menggunakan penelitian tindakan kelas. Penelitian dilakukan pada siswa kelas IV SD Islam Al Hikmah. Subjek dalam penelitian terdiri dari 28 siswa. Nilai hasil belajar siswa kelas IV pada siklus I menunjukkan siswa yang tuntas 21 siswa dengan presentase $75 \%$, sedangkan pada siklus II menunjukkan siswa yang tuntas 24 siswa dengan presentase $85 \%$. Hasil dari penelitian ini dapat disimpulkan bahwa penggunaan Peta Indonesia dan model pembelajaran TGT dapat meningkatkan aktivitas dan hasil belajar siswa kelas IV SD Islam Al Hikmah Gadang Malang.
\end{abstract}

\section{ABSTRACT}

Collaboration Of Indonesian Map And Teams Games Tournaments (Tgt) Learning

Model. The use of Peta Indonesia media and TGT learning models that involve students as peer tutors is easy to implement without any difference between smart or lacking students, where this collaboration is packaged in a game so that it becomes more effective and enjoyable learning, so as to improve learning activities and outcomes. The observation shows that the learning process takes place in the same direction so that students are more fun joking than learning. From this fact causes student learning outcomes tend to be low. It was proven that only $39.28 \%$ of 28 students achieved mastery learning, while $61.11 \%$ were under KKM 75.The purpose of the study was to describe the increase in activity and learning outcomes of fourth grade students of Al Hikmah Islamic Elementary School. The design of the study uses classroom action research. The study was conducted on fourth grade students of Al Hikmah Islamic Elementary School. The subjects in the study consisted of 28 students. The value of learning outcomes of class IV students in the first cycle shows students who completed 21 students with a percentage of $75 \%$, while in the second cycle showed students who completed 24 students with a percentage of $85 \%$. The results of this study can be concluded that the use of Indonesian Maps and TGT learning models can improve the activity and learning outcomes of fourth grade students of $A l$ Hikmah Gadang Islamic Elementary School Malang.

Copyright $@ \overline{2019 \text { (Siti Halimatus Sakdiyah }}{ }^{a, 1^{*}, \text { Triwahyudianto }^{b, 2}, \text { Harun }^{c, 3} \text { ). All Right Reserved }}$

How to Cite: Rahmawati, S. (2018). Pengaruh Logic Exercises Terhadap Disorientasi Moral Jugdment Mahasiswa: Studi Kasus Terorisme. Jurnal Moral Kemasyarakatan, 3(1), 1-10.

This work is licensed under a Creative Commons Attribution-ShareAlike 4.0 International License. Allows readers to read, download, copy, distribute, print, search, or link to the full texts of its articles and allow readers to use them for any other lawful purpose. The journal hold the copyright. 


\section{Pendahuluan}

Tujuan pengajaran pada kurikulum 2013 di SD/ MI adalah: (1) mengintegrasikan sikap, ketrampilan dan pengetahuan dalam proses pembelajaran, (2) sebuah tema dapat mengintegrasikan berbagai konsep dasar yang berkaitan, (3) siswa tidak belajar konsep dasar secara parsial, sehingga memberikan makna yang utuh kepada siswa seperti tercermin pada berbagai tema. Dengan demikian Kurikulum 2013 yang diaplikasikan di tingkat sekolah dasar (SD) banyak merubah metode evaluasi. Materi tak akan disampaikan per mata pelajaran tetapi per tema. Jenis evaluasi tematik integratif dijadikan tema sebagai pengikat beragam materi mata pelajaran. Dari semua kompetensi dasar terintegrasi ke dalam tema. Didalam satu tema terdapat berbagai macam mata pelajaran yaitu IPS, IPA, PKn, SBK dan Bahasa Indonesia.

Pada kenyataannya didalam praktek pembelajaran kurikulum 2013 di SD Islam Al Hikmah, guru masih menggunakan model pembelajaran konvensional dengan metode ceramah dan tanya jawab saja. Sehingga proses pembelajaran hanya berlangsung satu arah saja, tidak terjalin komunikasi antar guru dan siswa. Guru menjadi pusat pembelajaran dan sering sebagai penentu segalanya di dalam kelas. Tidak lepas dari itu saja, pembelajaran yang terjadi disesuaikan dengan kondisi psikologis guru yang mengajar. Ini dibuktikan ketika suasana hati guru baik dan senang maka ia mengajar dengan baik dan menyenangkan, tetapi jika suasana hatinya tidak enak sedang memiliki masalah pribadi dan belum terselesaikan maka guru hanya memberikan tugas saja. Akibatnya suasana belajar di kelas menjadi kurang menarik dan tidak nyaman, menegangkan dan sekaligus membosankan.

Selain itu dengan kondisi yang demikian, siswa dalam kelas cenderung pasif, kurang tanggap, dan hanya menggantungkan kepada guru. Karena pembelajaran hanya terjadi searah maka siswa lebih asyik mengobrol dengan teman dari pada mendengarkan pelajaran dari guru. Tidak terjalinnya komunikasi dalam pembelajaran, baik hanya sekedar tatap mata, sentuhan maupun teguran halus dan pujian menyebabkan timbulnya jarak antara guru dan siswa yang semakin jauh. Dari kenyataan semacam ini menyebabkan hasil belajar siswa cenderung rendah. Terbukti dari hasil penilaian formatif yang dilakukan di kelas IV terhadap tema indahnya kebersamaan dan ternyata hasilnya hanya 39,28\% dari 28 siswa (laki-laki 17, perempuan 11) yang mencapai ketuntasan belajar, sedangkan $61,11 \%$ mendapatkan nilai di bawah Kriteria ketuntasan Minimal (KKM) 75.

Dari kenyataanya tersebut ternyata model pembelajaran yang diterapkan guru selama ini kurang efektif guru hanya menggunakan ceramah tanpa menggunakan media, padahal peta Indonesia bisa digunakan oleh guru untuk menjelaskan tema Indahnya kebersamaan, guru juga jarang memberikan kesempatan siswa untuk bertanya dan berpendapat, tidak ada interaksi antara siswa dengan siswa lainya dalam bentuk kerjasama serta setrategi mengaitkan tema dalam pembelajaran belum tercapai dengan baik, sehingga hasil belajarnya rendah. Siswa belum memahami materi dan siswa tidak aktif. Padahal pada Tema Indahnya kebersamaan ini siswa di tuntut untuk saling bekerjasama, menghargai pendapat teman, dan tanggung jawab serta siswa dapat mencari jawaban sendiri dari proses belajar (student centre). Terlihat pada hasil observasi di kelas IV siswa belum mencapai hasil belajar yang maksimal dari tujuan pembelajaran pada tema indanya kebersamaan. Pada dasarnya tujuan pembelajaran tema indahnya kebersamaan yang sesuai dengan tujuan dalam kurikulum, untuk mempersiapkan insan Indonesia supaya memiliki kemampuan hidup sebagai pribadi dan warganegara yang beriman, produktif, kreatif, inovatif, dan afektif serta mampu 
berkontribusi pada kehidupan bermasyarakat, berbangsa, bernegara dan peradaban dunia (Permendiknas no. 67 tahun 2013). Menurut Dimyati (2009: 114) keaktifan siswa dalam pembelajaran memiliki bentuk yang beraneka ragam, dari kegiatan fisik yang mudah diamati sampai kegiatan psikis yang sulit diamati. Kegiatan fisik yang dapat diamati diantaranya adalah kegiatan dalam bentuk membaca, mendengarkan, menulis, meragakan, dan mengukur. Sedangkan contoh kegiatan psikis diantaranya adalah seperti mengingat kembali isi materi pelajaran pada pertemuan sebelumnya, menggunakan khasanah pengetahuan yang dimiliki untuk memecahkan masalah, menyimpulkan hasil eksperimen, membandingkan satu konsep dengan konsep yang lain, dan lainnya, adapun hasil belajar merupakan pengukur dari kemampuan siswa menurut Sudjana (2004:2) mengemukakan bahwa hasil belajar adalah kemampuan-kemampuan yang dimiliki siswa setelah menerima pengalaman belajar

Kurikulum adalah instrumen pendidikan untuk dapat membawa insan Indonesia memiliki kompetensi sikap, pengetahuan, dan keterampilan sehingga dapat menjadi pribadi dan warga negara yang produktif, kreatif, inovatif, dan efektif. Selain itu banyak guru yang belum paham dan memahami kurikulum 2013. Pada dasarnya siswa yang aktif akan lebih berperan aktif dalam melaksana pembelajran dan tidak tertinggal, guru sebagai tutor dan seseorang yang mengarahkan sebuah pembelajaran agar terlihat hidup karena partisipasi dari siswanya. Oleh karena itu, perlu dilakukan perbaikan pembelajaran baik dari segi model, metode, media maupun strategi belajarnya.

Dari hasil observasi tersebut, peneliti merasa terdorong untuk memberikan perbaikan terhadap kegiatan pembelajaran yaitu dengan model pembelajaran Team Game Tournament $(T G T)$. TGT adalah suatu model pembelajaran yang melibatkan siswa sebagai tutor sebaya dan mudah untuk diterapkan tanpa ada perbedaan antara siswa yang pandai atau kurang dan dikemas dalam permainan yang dilakukan guru agar menjadi pembelajaran yang lebih efektif, menyenangkan, melibatkan siswa, menemukan kreatifitas siswa dan hasil belajar yang meningkat. Oleh karena itu, peneliti mengajukan perbaikan kualitas pembelajaran pada indahnya kebersamaan dengan menerapkan model pembelajaran Team Game Tournaments (TGT) dan penggunaan peta Indonesia. Peneliti memilih penggunaan peta Indonesia dan model pembelajaran ini dikarenakan memiliki beberapa keunggulan dan cocok untuk di terapkan dengan kondisi kelas semacam ini pada tema Indahnya kebersamaan karena siswa terlibat langsung dalam proses pembelajaran. Seperti misalnya menempel gambar pakaian adat, rumah adat, tarian daerah dan alat-alat musik tradisional di masing-masing propinsi. Hal ini dijelaskan oleh Julianto (2011:49) bahwa model pembelajaran TGT dapat melibatkan siswa dalam proses pembelajaaran tanpa ada perbedaan status, memberikan kesempatan siswa untuk bisa berintraksi dengan baik kepada temanya tanpa ada perbedaan status, siswa belajar dalam kelompok, terdapat games dalam pembelajaran, terdapat kompetisi antar kelompok melalui games yang diberikan guru serta adanya penghargaan kepada pemenang tournament antar kelompok sebagai upaya memotivasi dan menciptakan komunikasi antara guru dan siswa.

Selain itu juga dipertegas oleh Trianto (2007:44) dalam bukunya bahwa penerapan model pembelajaran TGT ini dapat meningkatkan kinerja siswa dalam menyelesaikan tugas yang diberikan guru, anak terpacu untuk mencari informasi dan belajar, terjadi komunikasi antara siswa dalam kelompok, dapat meningkatkan motivasi belajar siswa, lebih memahami 
konsep materi yang diberikan dan menumbuhkan sikap percaya diri, trampil, kritis, dan kreatif.

\section{Metode}

Penelitian ini dirancang dengan menggunakan penelitian tindakan kelas (PTK). Model ini terdiri dari siklus-siklus yang paling berhubungan dimana masing-masing siklus terdiri dari beberapa tahapan: (1) perencanaan tindakan, (2) pelaksanaan tindakan, (3) observasi (pengamatan), (4) refleksi, apabila siklus I belum mencapai tujuan yang ditargetkan, maka dilanjutkan dengan siklus II yaitu perbaikan rencana, tindakan, obesrvasi dan refleksi. Apabila siklus II juga belum mencapai target maka dilanjutkan dengan siklus berikutnya yang selalu dimulai dengan perbaikan tindakan dari siklus sebelumnya.

Pada penelitian ini yang menjadi subjek penelitian adalah siswa kelas IV SD Islam Al Hikmah Gadang Malang dengan jumlah siswa 28 orang, yang terdiri 11 siswa laki-laki dan 17 siswa perempuan. Adapun instrumen penelitian yang digunakan yaitu: Tes, digunakan untuk mengukur kemampuan siswa dalam menganalisis materi pelajaran yang diberikan. Lembar observasi: lembar pengamatan yang diisi oleh observer. Hal ini dilakukan untuk mengetahui aktifitas siswa selama proses pembelajaran berlangsung. Rencana pelaksanaan pembelajaran (RPP) yang dipakai penelii adalah rencana pelaksanaan pembelajaran K13.

Analisis data dilakukan pada akhir pembelajaran untuk memperoleh data hasil belajar siswa. Rumus cara menghitung nilai hasil belajar

Keterangan:

$$
K B \frac{\Sigma \text { siswa yang memperoleh skor } \geq 75}{\Sigma \text { Jumlah siswa }} \times 100
$$

KB: ketuntasan hasil belajar

\section{Hasil dan pembahasan}

\section{Hasil temuan pada Aktivitas Guru}

Dari data-data observasi aktivitas guru pada siklus I sebesar 77\%. Pada siklus II sebesar 94\% dan Jika ditinjau dari tingkat keberhasilannya telah mengalami kenaikan dari siklus I ke siklus II sebesar $17 \%$. Lebih jelasnya diuraikan pada diagram perbandingan di bawah ini:

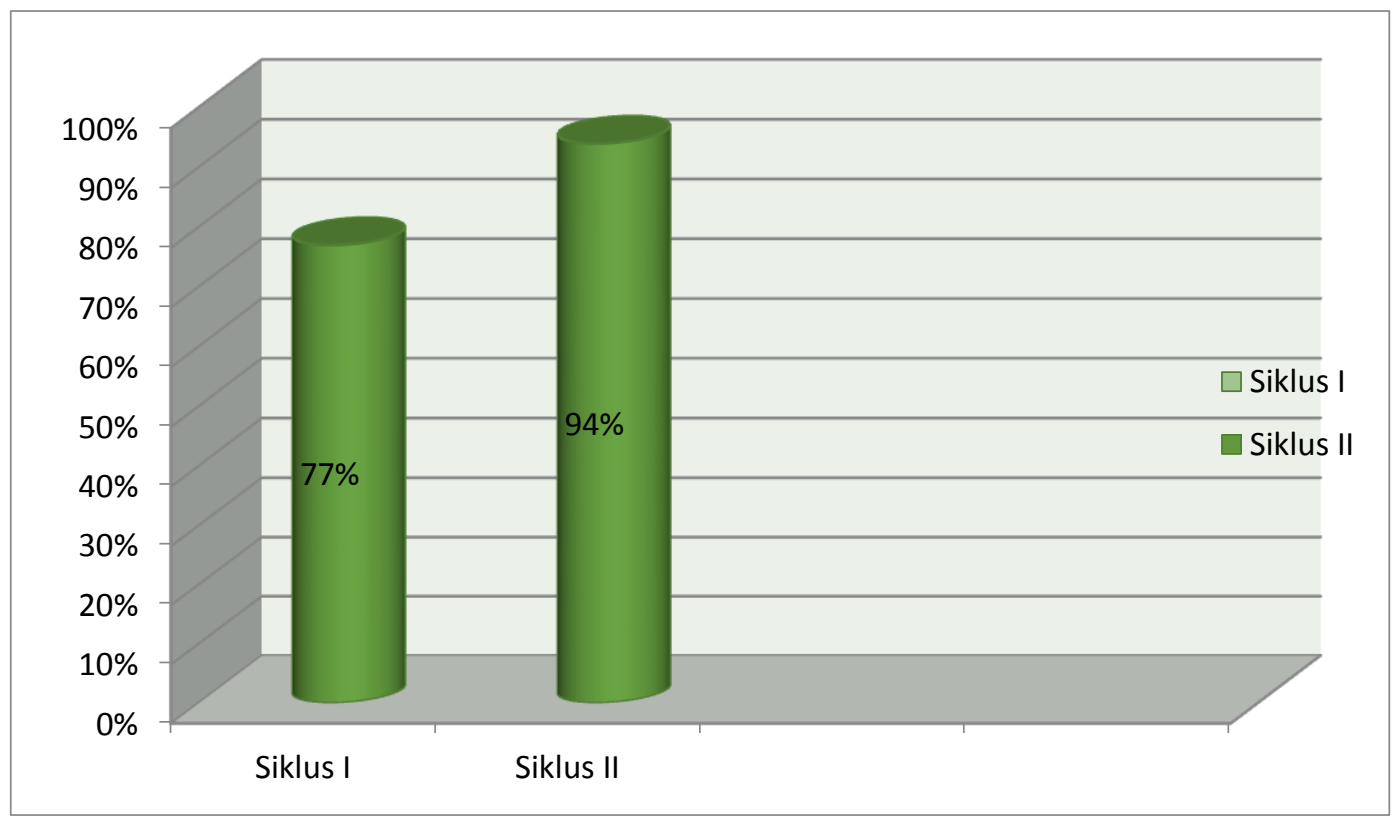

Diagram 1 : Aktivitas Guru 
Adapun temuan dari kekurangan yang dilakukan dalam siklus I antara lain (1) ketika guru menyampaikan materi kurang dapat dipahami dengan baik oleh siswa karena nada dan intonasi kurang jelas dan terlalu cepat, (2) membentuk kelompok belajar, (3) meminta siswa mempresentasikan hasil kerja kelompok, (4) menyimpulkan materi, dan (6) melaksanakan Game Turnamen serta mencatat poin nilai. Dari permasalahan yang ada tersebut peneliti dan obsever mencoba menghadirkan beberapa langkah perbaikan yaitu dengan cara: (1) lebih menguasai kelas, (2) menciptakan motivasi yang bagus dan membangkitkan semangat belajar siswa, (3) memberikan tmbahan buku ajar kepada siswa,(4) meminta siswa lebih jelas dan tidak malu-malu dalam mempresentasikan tugas dan (5) menguasai game dan turnamen yang diberikan pada siklus berikutnya dan menyiapkan bangku turnamen, membagi kelompok turnamen, membuat kartu soal dan lembar penilaian.hasil observasi aktivitas guru pada siklus II. Pada siklus II ini hasil observasi aktivitas guru menunjukkan kategori "baik" dan pencapaian persentasenya sebesar 77\%. Berdasarkan hasil tersebut aktivitas guru dalam penerapan model pembelajaran TGT belum mencapai indikator keberhasilan sebesar $80 \%$, oleh karena itu diterapkan siklus II dan melakukan perbaikan pembelajaran. Adapun kekurangan yang dilakukan dalam siklus II adalah dalam kurang memotivasi siswa, penyampaian materi dan pelaksanaan game dan turnamen serta penyampaian nilai guru lupa tidak menyebutkan tetapi hanya mengumumkan pemenang turnamen. Adapun hal-hal yang harus dilakuka guru pada siklus II antara lain (1) lebih menguasai kelas, (2) menciptakan motivsi yang lebih bagus dan membangkitkn semangat belajar siswa, (3) meminta siswa lebih jelas dan tidak malumalu dalam mempresentasikan tugas, (4) menguasai game dan turnamen yang diberikan dan (5) tidak lupa memberikan informasi terhadap nilai yang diperoleh siswa dalam games dan turnament.

Kegiatan siklus II ini dilakukan karena hasil kegiatan siklus I belum mampu mencapai indikator keberhasilan penelitian oleh karena itu peneliti melakukan Siklus II. Setelah semuakegiatan pada siklus II dilakukan didapatkan hasil observasi dan simpulan bahwa pada siklus II ini aktivitas guru mencapai $90 \%$ dengan predikat sangat baik karena seluruh indikator dan langkah-langkah pembelajaran dalam RPP di siklus II ini terlaksana dengan baik. Dari analisis data yang ada ternyata aktifitas guru mengalami peningkatan dalam tiap siklus yang dilaksanakan. Hal ini menunjukkan bahwa penerapan model pembelajaran mampu mengaktifkan komunikasi antar guru dengan siswa, guru lebih berberan sebagai pusat informasi, pembimbing yang dapat siswa tanya dan minati pendapat tentang hal yang dilakukan. Selain itu peran siswa sebagai tentor sebaya juga sudah dapat terlihat dari diskusi-diskusi yang dilakukan dalam kelompok yang melebur perbedaan yang ada dalam kelompok. Tumbuh pula sikap berani berpendapat, bertanya, dan rasa percaya diri untuk menyampaikan hasil karya yang dibuatnya dalam kelompok dan mampu bersaing secara sehat dalam turnamen. Hal ini sejalan dengan kelebihan model pembelajaran TGT sesuai yang disampaikan oleh Trianto (2007:44). Dengan demikian dapat disimpulkan bahwa aktivitas guru dalam menerapkan model pembelajaran TGT telah tercapai dan aktivitas guru mengalami peningkatan.

\section{Hasil Temuan pada aktivitas siswa}

Dalam keberhasilan suatu pelaksanaan pembelajaran, siswa juga merupakan salah satu komponen terpenting selain guru. Pengelolaan pembelajaran yang dilakukan oleh guru juga akan mempengaruhi aktivitas siswa dalam proses pembelajaran. Pada siklus I dapat dikatakan bahwa aktivitas siswa masih tergolong rendah, hal tersebut mendorong guru untuk melakukan perbaikan dalam proses pembelajaran dan mencari solusi dari permasalahan-permasalahan yang ditemukan di siklus I. Aktivitas siswa selama proses pembelajaran ke 5 pada tema indahnya kebersamaan pada siklus I diperoleh presentase rata-rata $79 \%$. Hal ini menunjukkan bahwa aktivitas siswa pada siklus I belum mencapai kriteria yang ditetapkan yaitu $80 \%$. Berdasarkan refleksi yang dilakukan pada siklus I, aktivitas siswa yang masih kurang yaitu (1) membentuk kelompok belajar, (2) menyimpulkan materi, (3) melaksanakan game dan turnamen serta mencatat poin turnamen. Kemudian Guru melakukan perbaikan yaitu (1) siswa harus lebih serius ketika menyimak penjelasan guru, (2) siswa harus lebih tertib dalam diskusi kelompok mengerjakan LKS dan mempresentasikan, (3) siswa mengerjakan lembar evaluasi dengan tenang dan jujur dan (4) melaksanakan game dan turnament yang diberikan guru dengan baik.

Oleh karena itu penelitian berusaha memperbaiki aktivitas pembelajaran agar siswa dalam siklus II menjadi lebih aktif. Dari hasil pelaksanaan siklus II ini diperoleh hasil bwah aktivitas siswa dapat mencapai prosentase sebesar $92 \%$. Hal ini menunjukkan bahwa aktivitas siswa dalam pembelajaran 
ini telah tercapai dengan baik dan dapat meningkat pada tiap siklus yang dilakukan. Adapun lebih jelas dapat dilihat dalam diagram perbandingan aktivitas siswa pada tiap siklus di bawah ini.

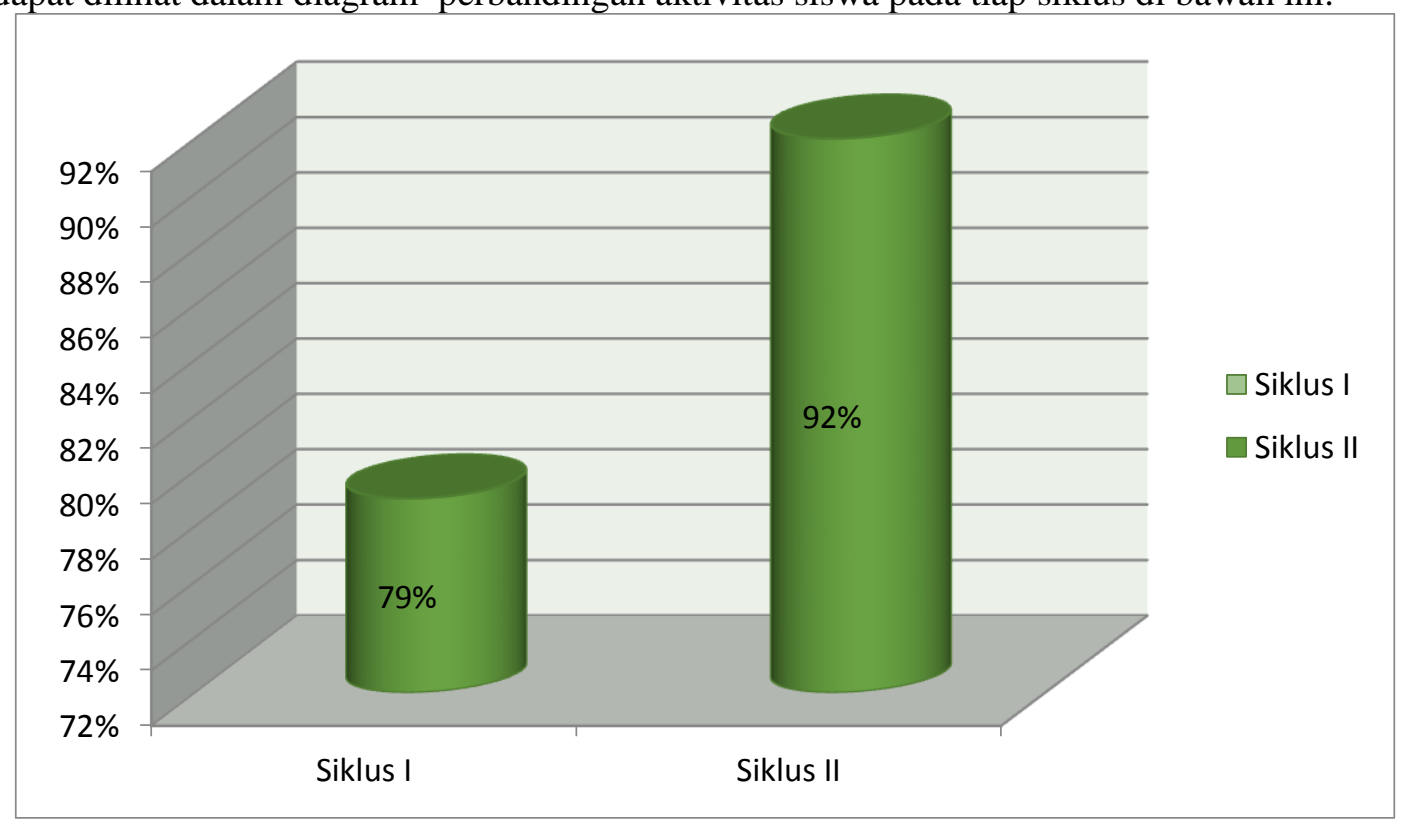

Diagram 2 : Aktivitas Siswa Dalam Penerapan Model TGT di kelas IV pada Siklus I dan II

Dari berbagai diagram aktivitas yang telah siswa lakukan dalam penelitian mengalami kenaikan dalam tiap tahapan siklus yang dilakukan ini disebabkan dari faktor dari siswa yang telah benar-benar siap untuk menerima pembelajaran dan motivasi yang telah guru berikan mengena kepada siswa sehingga perasaan senang akan pembelajaran yang dilakukan dapat secara optimal diserap siswa. Selain itu faktor kesehatan siswa juga mempengaruhi daya serap siswa terhadap pembelajaran yang dilakukan. Adapun faktor lingkungan sekolah dan keluarga juga mempengaruhi kesuksesan siswa dalam menerima pelajaran hal semacam ini sejalan dengan apa yang disampaikan oleh Sudjana (2004:2) bahwa faktor keberhasilan pembelajaran yaitu faktor internal dan eksternal dari diri siswa tersebut.

Selain itu kegiatan pembelajaran yang dilakukan telah mencapai tujuan dalam kurikulum 2013 tentang pendidikan karakter pada pembelajaran 5 di tema indahnya kebersamaan subtema 1 keberagaman budaya bangsaku yaitu (a) memiliki penghargaan dan pengertian terhadap nilai-nilai, pranata, dan praktik kehidupan kemasyarakatan. Hal ini tercemin dalm nilai siswa dalam menjaga kekayaan budaya bangsa untuk tidak meniru sikap mencorat-coret rumah adat istiadat, mampu menjaga baik dengan baik dan mengenalkan kepada yang lain. (b) memiliki rasa toleransi yang besar dengan yang lain dalam bekerjasama menyelesaikan suwatu permasalahn (c)memiliki sikap intergritas sosial dan tanggung jawab sebagai warga (d) mempunyai pengertian dan penghargaan terhadap nilainilai budaya atau tradisi yang diwariskan oleh bangsanya. Dari tujuan itu siswa kelas IV sudah mampu untuk memiliki sikap toleransi dan tanggung jawab terhadap pekerjaan yang telah guru berikan. Ini dapat dilihat dari aktivitas siswa ketika berdiskusi, presentasi, bertanya kepada guru dan sikap mau menolong teman serta jujur terhadap apa yang ia lakukan. Dari semua aspek yang telah siswa lakukan dalam tiap siklus yang diamati oleh obsever memang terbukti aktifitas siswa mengalami perkembangan lebih baik dibandingkan dengan hasil temuan awalnya.

\section{Hasil Belajar Siswa}

Pada siklus I hasil belajar siswa untuk sub tema keberagaman budaya bangsaku pada tema indahnya kebersamaan dengan kolaborasi peta Indonesia dan model pembelajaran TGT diperoleh nilai rata-rata 74 dan persentase ketuntasan belajarnya sebesar $75 \%$. Berdasarkan persentase tersebut dapat dikatakan bahwa siswa yang memperoleh skor lebih atau sama dengan 75 ada 21 siswa. Nilai tersebut menandakan bahwa pembelajaran kali ini belum berhasil karena masih banyak nilai siswa yang belum mencapai KKM. Hal ini 
terjadi karena kurangnya bimbingan dalam proses pembelajaran dan kurang menguasai kelas sehingga siswa bermain sendiri. Berdasarkan refleksi yang dilakukan pda siklus I dengan melakukan perbaikan terhadap kinerjanya dalam proses pembelajaran, didapatkan peningkatan hasil belajar siswa pada siklus II yaitu rata-rata 82,5 dengan kategori "baik" dan pencapaian persentase 92,8\%. Dari penerapan siklus II didapatkan hasil belajar siswa mengalami peningkatan, terbukti 26 dari 28 siswa kelas IV mencapai nilai lebih dari sama dengan 5 dengan persentase perolehan nilai siswa yang lulus mencapai $89 \%$ dari jumlah siswa. Adapun kenaikan hasil belajar dari temuan awal sebesar 17,8 \% siswa tuntas belajar, pada siklus I siswa tuntas belajar sebesar 75\%, pada siklus II mencapi $92,8 \%$ siswa tuntas belajar. Dari uraian tersebut dapat dibuat grafik perbandingan dan kenaikan hasil belajar siswa mulai dari temuan awal siklus I dan II dalam penggunaan peta Indonesia dan model TGT di kelas IV SD Islam Al Hikmah berikut ini:

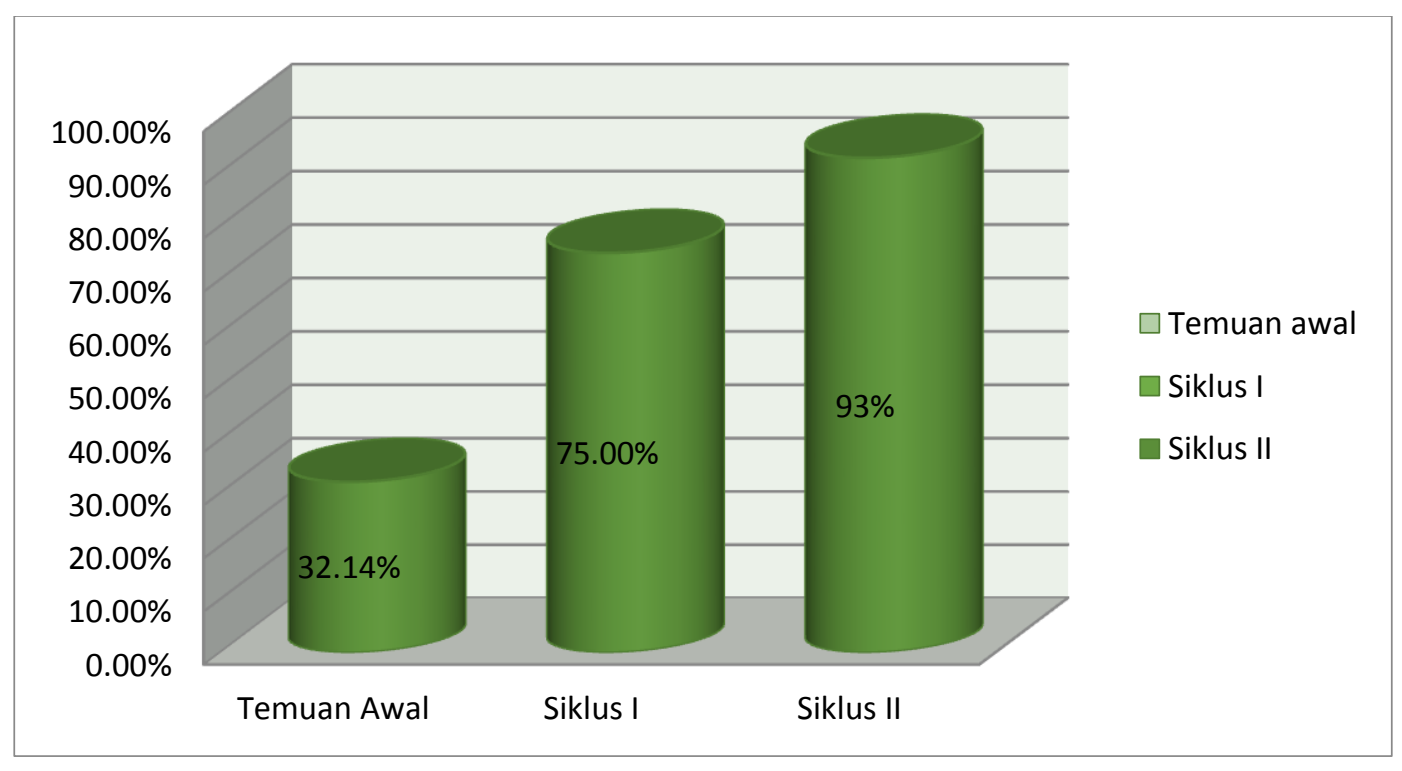

Diagram 3 : Perbandingan Hasil Belajar Siswa

Dengan melihat hasil belajar siswa ketika model TGT diterapkan di kelas IV tentang hasil balajar secara kognitif dalam tiap siklus terjadi peningkatan yang signifikan. Hal ini dapat terjadi karena beberapa faktor sesuai dengan yang diutarakan oleh Slameto (2003:54), bahwa hasil belajar siswa itu dipengaruhi oleh faktor internal dan faktor eksternal. Adapun faktor internal yang mendukung keberhasilan penerapan model TGT ini adalah kondisi kesehatan siswa secara jasmaniah sehat terbukti siswa kelas IV selalu masuk ketika guru melaksanakan pembelajaran dengan model TGT ini. Selain itu siswa juga sudah mulai merasakan perbedaan pembelajaran yang terjadi, muncul perasaan nyaman, senang dan tertarik dari dalam diri siswa masing-masing. Adapun faktor eksternal yang mendukung pembelajaran ini adalah faktor lingkungan sekolah untuk terjadinya proses pembelajaran yang menyenangkan dan nyaman, guru tidak lagi menjadi orang yang berkuasa penuh di dalam kelas tetapi sudah menjadi teman belajar.

Selain itu keberhasilan pembelajaran yang telah dilakukan telah mencapai kriteria yang diungkapkan oleh Sudjana (2004:2) bahwa hasil belajar yang berhasil memiliki ciri bahwa: (1) kepuasan dan kebanggaan yang dapat menumbuhkan motivasi pada diri siswa, ini terbukti dengan siswa merasa senang dan puas ketika ditanya tentang kegiatan pembelajaran yang 
Jurnal Inspirasi Pendidikan, VOL.9, NO.1, Edisi Januari 2019

Kolaborasi Peta Indonesia Dan Model Pembelajaran Teams Games Tournaments (TGT) Siti Halimatus Sakdiyah ${ }^{\text {a, }}{ }^{*}$, Triwahyudianto ${ }^{\text {b, } 2}$, Harun ${ }^{\text {c, } 3}$

telah dilakukan. (2) Menambah keyakinan akan kemampuan dirinya, keyakinan ini muncul dan dapat dilihat ketika siswa melaksanakan turnamen, siswa tidak lagi yang ragu dalam menjawab pertanyaan juga keberhasilan siswa untuk mau bertanya kepada guru ketika mengalami kesulitan . (3) Hasil belajar yang dicapai bermakna bagi dirinya seperti akan tahan lama diingatannya, membentuk perilakunya, bermanfaat untuk mempelajari aspek lain, dapat digunakan sebagai alat untuk memperoleh informasi dan pengetahuan yang lainya. Hal ini dapat dilihat ketika siswa diminta menjelaskan sikap harus dan sebaiknya dilakukan terhadap cara menghargai kebudayaan bangsa mereka memberikan jawaban yang baik untuk menunjukkan sikap menghargai akan budaya dan kerjasama antar temannya. (4) Kemampuan siswa untuk mengontrol atau menilai dan mengendalikan dirinya terutama dalam menilai hasil yang dicapainya maupun menilai dan mengendalikan proses dan usaha belajarnya.

\section{Simpulan}

Aktivitas siswa selama proses pembelajaran dengan menggunakan model pembelajaran Team Game Tournement (TGT) meningkat dalam arti aktif mencari materi untuk memecahkan masalah, berdiskusi dan mampu bertanya kepada guru dan teman lain. Hasil belajar siswa setelah proses pembelajaran dengan menggunakan model pembelajaran Time Game Tournament (TGT) meningkat dalam tiap tahap penelitian. Hal ini ditandai ketuntasan minimal selama dua siklus penelitian yang dilakukan.

\section{Referensi}

Fitri, 2014. Pembelajaran Kooperatif Tipe Team Game Tournament (TGT) untuk Meningkatkan Hasil Belajar Siswa Kelas VII SMP Negeri 1 Purwodadi Kabupaten Pasuruan Pada Materi Keragaman Bentuk muka bumi. Tesis tidak diterbitkan.Malang Jurusan Pendidikan Geografi, Program Pasca Sarjana Universitas Negeri Malang.

Julianto,dkk. 2011. Teori dan Implementasi Model-Model Pembelajaran Inovatif. Surabaya: Unesa University Press

Kemretrian Pendidikan dan Kebudayaan 2013. Indahnya Kebersamaan.Jakarta: Kementrian Pendidiakan dan Kebudayaan.Mustaqim, Burhan.2008.Ayo Belajar Matematika 4 :untuk SD dan MI kelas IV.Jakarta:Pusat Perbukuan, Departemen Pendidikan Nasional.

Sudjana, Nana. 2004. Penilaian Hasil Proses Belajar Mengajar. Bandung: Remaja Rosdakarya

Slameto. 2010. Belajar dan Faktor-faktor Yang Mempengaruhi. Jakarta: Rineka Cipta

Trianto, 2007. Model-Model Pembelajaran Inovatif Berorientasi Konstruktivistik. Jakarta: Prestasi Pustaka 